\title{
Assay of Bordetella pertussis heat-labile toxin with human embryonic lung cells
}

\author{
HELEN K. FRAMPTON,* J. H. FREER, † T. H. BIRKBECK and A. C. WARDLAW \\ Department of Microbiology, University of Glasgow, Glasgow G12 $8 Q Q$
}

\begin{abstract}
Summary. An assay has been developed for Bordetella pertussis heat-labile toxin (HLT) based on morphological alterations in certain human embryonic lung (HEL) cell lines. Eighteen cell lines from human and other sources were tested but only two, MRC-5 and HELu2, were responsive to HLT. Confluent monolayers of the cells contracted within $24 \mathrm{~h}$ of exposure to the toxin, but without loss of viability during incubation for a further 3 days. The effect of HLT was quantitated by scoring the extent of morphological change, and by the decrease in Giemsa staining of the cell monolayers, as measured on an ELISA plate reader. This cell culture assay for HLT was more sensitive than lethality titration in mice but the doseresponse curve had a lower slope. The specificity of the response was established by comparing unheated HLT with HLT heated at $56^{\circ} \mathrm{C}$, and with extracts from transposoninsertion mutants of $B$. pertussis which were deficient in HLT. Purified preparations of pertussis toxin and $B$. pertussis lipopolysaccharide gave no morphological response even at high doses.
\end{abstract}

\section{Introduction}

Virulent strains of Bordetella pertussis produce several toxins ${ }^{1}$ and it is the heat-labile toxin (HLT) which is principally responsible for the mouse-lethal toxicity of freshly harvested bacteria. This toxin, first demonstrated by Bordet and Gengou in $1909,{ }^{2}$ is characterised by its dermonecrotising activity after subcutaneous injection into mice, rabbits and guinea pigs. ${ }^{3} \mathrm{It}$ is inactivated by heating at $56^{\circ} \mathrm{C}$ for $30 \mathrm{~min}$, a lability which distinguishes it from the other toxins of $B$. pertussis.

Progress in purifying HLT and determining its mode of action has been hampered both by its lability and by the lack of a convenient in-vitro assay. Reports of HLT affecting tissue culture cells from various sources are confusing and contradictory. For example, Strizova and Trlifajova ${ }^{4}$ described morphological alterations of primary cultured cells of embryonic tissue apparently induced by HLT. However, the active factor was not eliminated by heating for $30 \mathrm{~min}$ at $56^{\circ} \mathrm{C}$, although $60 \mathrm{~min}$ at this temperature did destroy it. Kume et al. ${ }^{5}$ observed that HLT was cytotoxic for bovine embryonic lung cells, while Endoh et $a l .{ }^{6}$ found that HLT acted only on vascular smooth muscle cells.

Received 23 April 1990; accepted 17 July 1990.

* Present address: Hoescht Aktiengesellschaft, Clinical Research Department, D-6230 Frankfurt am Main 80, PO Box 800320 , Germany.

+ Correspondence should be sent to Professor J. H. Freer.
We report in this paper the screening of 18 mammalian cells lines with HLT and the detection of two lines in which the toxin produced morphological changes. The MRC-5 human embryonic lung (HEL) cells, in confluent monolayers, were chosen for further study.

\section{Materials and methods}

\section{Bacterial strains}

B. pertussis strains Tohama (originally obtained from the National Institutes of Health, Bethesda, MD, USA) and 77/18319 (a clinical isolate provided by the Department of Bacteriology, Ruchill Hospital, Glasgow) were used for the routine screening for HLTsensitive cell lines. The HLT extraction procedure was also applied to transposon-insertion mutants of $B$. pertussis strain Tohama (provided by Dr A. A. Weiss) which lacked various mouse-virulence factors including HLT. ${ }^{7}$ The mutant strains were: BP348 which lacks haemolysin (HLY) and adenylate cyclase toxin (ACT); BP353 which lacks filamentous haemagglutinin (FHA); BP357 which produces much reduced levels of pertussis toxin (PT); and BP 347 which lacks a functional virulence gene vir and, as a result, fails to express a number of virulence factors whose expression is under vir-gene control, notably HLT, PT, ACT, HLY and FHA. Recently ${ }^{8}$ bvg (Bordetella virulence gene) has been proposed as a more suitable designation for vir. 


\section{Crude $H L T$ and cytoplasmic fraction from $H L T^{-}$ mutants}

All strains of $B$. pertussis were plated on to BordetGengou (BG) Agar (Gibco) and incubated for $48 \mathrm{~h}$ at $36^{\circ} \mathrm{C}$ in a humidified atmosphere. The bacteria were harvested into pre-warmed sterile saline, and this cell suspension was used to inoculate the " $16 \mathrm{G}+1 \mathrm{P}$ " medium of Stainer and Scholte, ${ }^{9}$ but containing onequarter the specified amount of Tris, as detailed by Livey and Wardlaw. ${ }^{10}$ The harvest from the confluent growth on one 9-cm BG plate was inoculated into $1 \mathrm{~L}$ of the modified Stainer and Scholte medium in a $2-\mathrm{L}$ Ehrlenmeyer flask. After incubation at $36^{\circ} \mathrm{C}$ for $36 \mathrm{~h}$, with shaking at $150 \mathrm{rpm}$, the bacteria were harvested by centrifugation at $10000 \mathrm{~g}$ for $30 \mathrm{~min}$ at $4^{\circ} \mathrm{C}$ and the packed cells were resuspended in $c .10 \mathrm{ml}$ of ice-cold sterile saline. The bacteria were disrupted by a single passage through a pre-cooled $\left(4^{\circ} \mathrm{C}\right)$ French pressure cell. The broken cells were centrifuged at $100000 \mathrm{~g}$ for $60 \mathrm{~min}$ at $4^{\circ} \mathrm{C}$ and the supernate was designated either "crude HLT", or "cytoplasmic fraction" if it had been obtained from an $\mathrm{HLT}^{-}$mutant. It was sterilised by filtration through cellulose acetate membranes (pore size $0.45 \mu \mathrm{m}$ ) and stored at $-20^{\circ} \mathrm{C}$. Protein concentration was estimated by the Bradford method $^{11}$ with bovine serum albumin (Sigma) as standard.

\section{PT and lipopolysaccharide (LPS)}

Purified PT was supplied by Dr R. Parton (Department of Microbiology, University of Glasgow), prepared from strain BP353 grown in cyclodextrin liquid medium $^{12}$ as described by Christodoulides et al. ${ }^{13} \mathrm{~A}$ dose of $10 \mu \mathrm{g}$ of PT was equivalent to $7050 \%$ histamine-sensitising-doses (HSD50) as determined by the method of Christodoulides et al. ${ }^{13}$

Phase I B. pertussis endotoxin (LPS) was purchased from List Biological Laboratories Inc., Campbell, CA, USA.

\section{Mammalian cell culture}

Cell lines. The cell types of the 18 mammalian cell lines are given in table I. BHK-21, BS-C-1, CHO, HeLa 39, and HELu2 were provided by the Department of Virology, University of Glasgow; BEL, FLOW 2002, HEp2, KB, and MRC-5 were purchased from Flow Laboratories, Rickmansworth, Herts; BALB/c N, BNL, and $\mathrm{LTK}^{-}$were obtained from the Beatson Institute for Cancer Research, Glasgow; DBS-FCL-2, Don, HF19, MLg 2908, and WI-38 came from the European Collection of Animal Cell Cultures, PHLS Centre for Applied Microbiology and Research, Salisbury.

Culture of cells. All mammalian cell lines were incubated in an atmosphere of $\mathrm{CO}_{2} 5 \%$ and air $95 \%$ at $37^{\circ} \mathrm{C}$, in a special liquid medium (SLM) consisting of modified Eagle's Minimum Essential Medium with Earle's Salts (Gibco) containing twice the normal concentrations of amino acids and vitamins. SLM was supplemented with fetal calf serum (Flow Laboratories) $10 \% \mathrm{v} / \mathrm{v}, 4 \mathrm{mM}$ glutamine, benzylpenicillin $100 \mathrm{U} / \mathrm{ml}$, streptomycin $100 \mu \mathrm{g} / \mathrm{ml}$ and nystatin $50 \mathrm{U} /$ $\mathrm{ml}$ (Sigma). A split ratio of 1:5 was used routinely in subculturing the cells. Tissue culture plastics were purchased from Gibco, Paisley. Stocks of all mammalian cells were stored as described for MRC-5 cells. $^{14}$

Cell monolayers were used up to passage number 40 , then discarded. Beyond this stage there was an unacceptable deterioration in the sensitivity of the cells to HLT.

Fixing and staining. Cell monolayers were washed three times in situ with Dulbecco A phosphate-buffered saline (PBS), pH 6.8, and allowed to dry. Methanol was added and the cells were left at room temperature for $30 \mathrm{~min}$; the methanol was removed and the cells again allowed to dry. Monolayers were stained for 30 min with Giemsa solution (BDH) $10 \%$ in PBS, after which the cells were washed three times with PBS and allowed to dry.

Screening for sensitivity to HLT. Mammalian cells were seeded in microtitration plates at an initial density of $1 \times 10^{4}$ cells/well and incubated until confluent. At this stage, generally after 3-4 days, the tissue-culture medium was replaced (180 $\mu \mathrm{l} /$ well) and $20 \mu \mathrm{l}$ of crude HLT from strain Tohama or $77 / 18319$ was added. Four replicate wells were used for each dilution in a 10-fold dilution series. The final concentrations of bacterial protein ranged from $100 \mu \mathrm{g}$ to $0.1 \mathrm{ng}$ per $0.2 \mathrm{ml}$. Controls, consisting of crude HLT inactivated by heat $\left(56^{\circ} \mathrm{C}, 30 \mathrm{~min}\right)$, were tested simultaneously. The monolayers were examined microscopically for morphological changes at 24-h intervals over a 96-h incubation period.

Neutral-red assay for cell viability. This assay for cell viability was based on that of Greaves et al. ${ }^{15}$ with neutral red $0.05 \% \mathrm{w} / \mathrm{v}$ dissolved in saline and filtered through Whatman 3MM filter paper. Monolayers of cells in microtitration plates were washed twice in saline (pre-warmed to $37^{\circ} \mathrm{C}$ ); neutral red solution was then added $(200 \mu \mathrm{l} /$ well $)$ and the plates were incubated for $30 \mathrm{~min}$ at $37^{\circ} \mathrm{C}$. After washing the monolayers three times in saline, the plates were allowed to dry for at least $2 \mathrm{~h}$. Incorporated dye was extracted from the cells into $200 \mu \mathrm{l}$ of a buffer-alcohol mixture $(50 \mathrm{mM}$

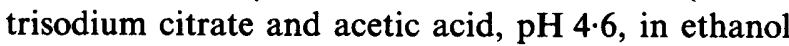
$50 \% \mathrm{v} / \mathrm{v})$. After $1 \mathrm{~h}$ the $\mathrm{A}_{540 \mathrm{~nm}}$ was measured in an ELISA plate reader (Titertek Multiskan, Flow Laboratories) and the replicate values at each dilution of toxin were summarised as the mean and $95 \%$ confidence limits.

MTT assay for cell viability. Mammalian cells were also tested for viability as described by Mosmann, ${ }^{16}$ except that only $1-h$ incubation was used. This method is based upon the ability of viable cells to reduce 34,5-(dimethylthiazol-2-yl)-2,5-diphenyl tetrazolium 
bromide (MTT) from a yellow substrate to a blue formazan product. Because large amounts of HLT protein interfered with the isopropanol solubilisation of the formazan product, the culture medium was replaced with PBS immediately before the assay.

\section{Assay of HLT in MRC-5 monolayers}

MRC-5 monolayers were incubated with 10-fold dilutions of HLT as described above and the extent of morphological change was assessed at 72 or $96 \mathrm{~h}$. Scores of $0,1,2,3$ and 4 were given to monolayers containing respectively $0,25,50,75$ and $>75 \%$ of altered cells. For each dilution of HLT, the quadruplicate monolayers yielded total scores from 0 to 16 , which were expressed as score ratios from $0 / 16$ to $16 /$ 16. From these ratios, the ED50 and $95 \%$ confidence limits were determined by the logit method, as used by Takano and $\mathrm{Kondo}^{17}$ to evaluate haemolysis ratios in the assay of the haemolytic activity of Clostridium septicum toxin. The statistical calculations were done with a logit computer programme supplied by $\mathrm{Dr} G$. Gettenby, Department of Statistics, University of Strathclyde, Glasgow.

\section{Assay of HLT in mice}

The lethality of HLT preparations was titrated in CD-1 mice, 3-4 weeks old, with 10 animals for each dilution of HLT. The mice were given $100 \mu \mathrm{l}$ of each dilution in sterile saline by intraperitoneal injection, and deaths were recorded for 3 days. The LD50 and $95 \%$ confidence limits were calculated by the logit method as described above for ED50.

\section{Results}

\section{Sensitivity of cell lines to $H L T$}

Eighteen mammalian cell lines (table I) were tested for sensitivity to HLT over a wide range of dilutions. The cells came from man, monkey, ox, mouse and hamster, and from various tissues including lung, liver, larynx, kidney and ovary. Carcinoma and fibroblast lines were also included. Only two cell lines, MRC-5 and HELu2, both from human embryonic lung tissue, showed any morphological alterations after exposure to crude HLT.

The MRC- 5 monolayers exhibited a contraction of the cells along the major axis, and subsequent development of irregular gaps in the cell sheet (fig. 1). The earliest time at which contraction appeared was $24 \mathrm{~h}$, after which the effect became more pronounced up to $72-96 \mathrm{~h}$, but no further changes were seen. The HELu2 cells gave results similar to MRC- 5 in time of onset and development, and in the extent of morphological changes. They also appeared to have a quantitatively similar sensitivity to HLT. From these observations, MRC-5 was chosen as the cell line for
Table I. Sensitivity of mammalian cell lines to $B$. pertussis HLT

\begin{tabular}{|c|c|c|}
\hline $\begin{array}{l}\text { Designation } \\
\text { of cell line }\end{array}$ & Cell type & $\begin{array}{c}\text { Effect of HLT during } \\
96-\mathrm{h} \text { exposure }\end{array}$ \\
\hline BALB/c N & Mouse fibroblast & Nil \\
\hline BEL & Bovine embryonic lung & Nil \\
\hline BNL & Mouse normal liver & Nil \\
\hline BHK-21 & Hamster kidney & Nil \\
\hline BS-C-1 & Monkey kidney & Nil \\
\hline $\mathrm{CHO}$ & Hamster ovary & Nil \\
\hline DBS-FCL-2 & Monkey lung & Nil \\
\hline Don & Hamster lung & $\mathrm{Nil}$ \\
\hline Flow 2002 & Human embryonic lung & $\mathrm{Nil}$ \\
\hline HeLa 39 & Human cervical carcinoma & Nil \\
\hline HELu2 & Human embryonic lung & Cell contraction \\
\hline HEp2 & Human larynx & Nil \\
\hline HF19 & Human fetal lung & Nil \\
\hline KB & Human oral carcinoma & Nil \\
\hline LTK & Mouse fibroblast & Nil \\
\hline MLg 2908 & Mouse lung & Nil \\
\hline MRC-5 & Human embryonic lung & Cell contraction \\
\hline WI-38 & Human embryonic lung & Nil \\
\hline
\end{tabular}

further investigation because it is well characterised, ${ }^{14,18}$ relatively easy to maintain, and readily available from commercial sources.

\section{Specificity of response of $M R C-5$ cells to $H L T$}

To determine whether the response produced by crude HLT in MRC- 5 cells was due to this toxin and not to PT or LPS, comparative tests were made with unheated $\mathrm{HLT}$ and $\mathrm{HLT}$ preparations heated at $56^{\circ} \mathrm{C}$.
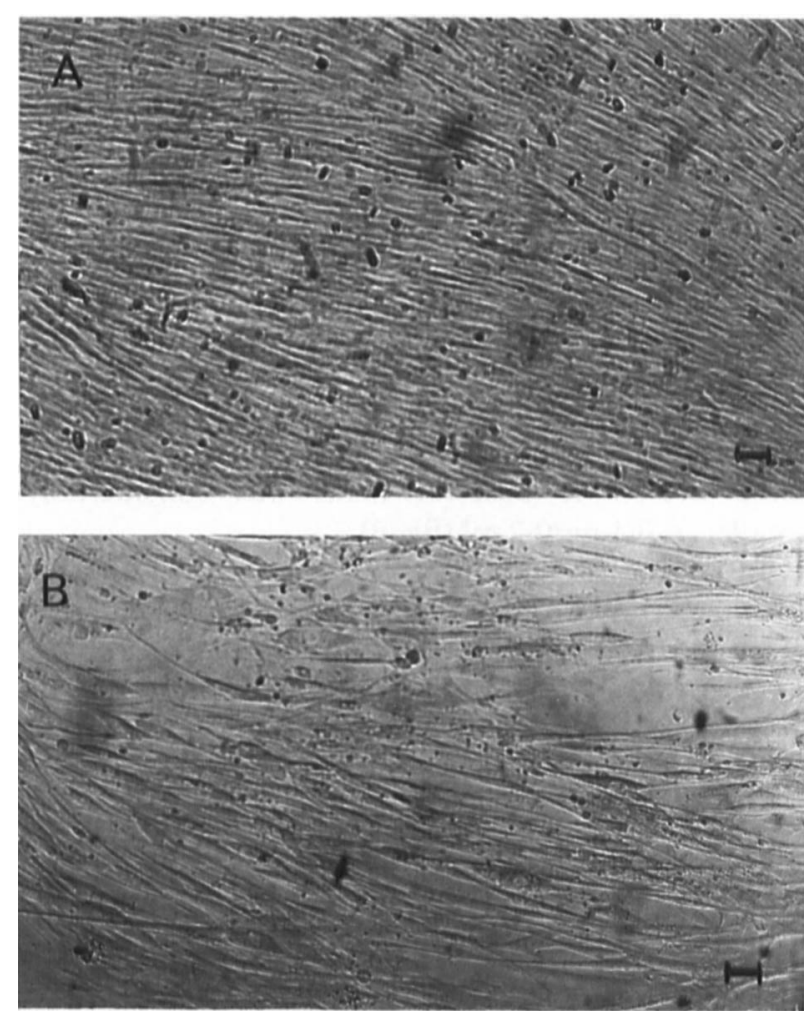

Fig. 1. Action of $B$. pertussis HLT on MRC-5 cells after $72 \mathrm{~h}$ at $37^{\circ} \mathrm{C}$. A, control cells; B, cells exposed to HLT. Bar $=10 \mu \mathrm{m}$. 


\section{$\log _{10}(\mu \mathrm{g}$ crude $\mathrm{HLT} / 0.2 \mathrm{ml})$}

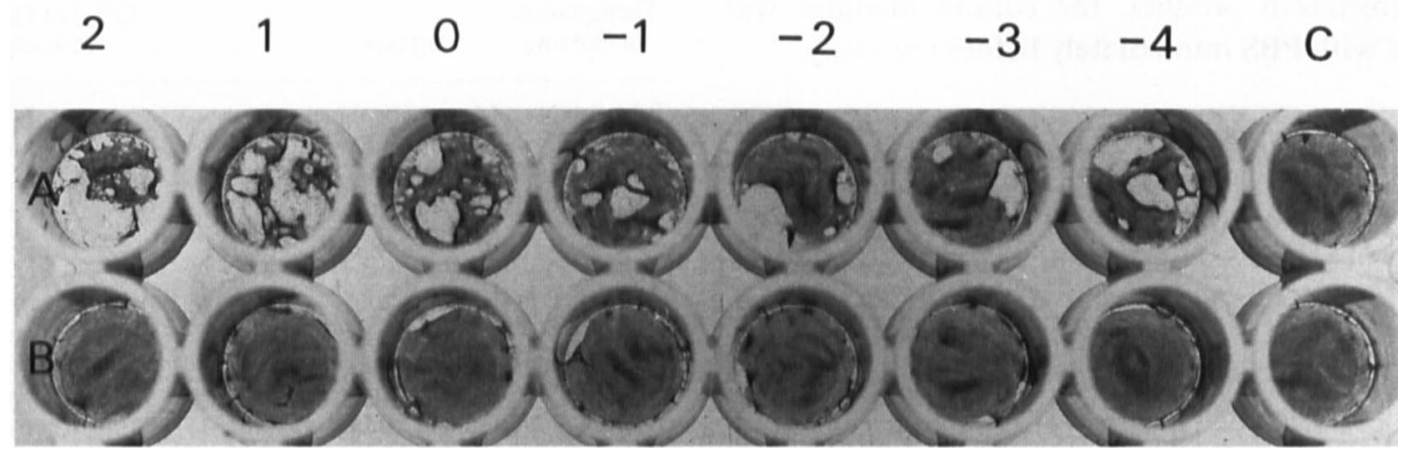

Fig. 2. Giemsa-stained monolayers of MRC-5 cells in microtitration wells after exposure for $72 \mathrm{~h}$ to different dilutions of crude $\mathrm{HLT}$ from $B$ pertussis strain $348\left(\mathrm{Hly}^{-}, \mathrm{Act}^{-}\right)$. A, unheated toxin; B, toxin heated for $30 \mathrm{~min}$ at $56^{\circ} \mathrm{C}$; $\mathrm{C}$, control (saline) wells.

As shown in fig. 2, the unheated HLT preparation from strain BP348 at $0 \cdot 1 \mathrm{ng} /$ well gave a definite response, whereas the corresponding $56^{\circ} \mathrm{C}$-heated sample was completely inactive even at $100 \mu \mathrm{g} /$ well, indicating more than $10^{6}$-fold loss of activity. Since PT and LPS are not inactivated at $56^{\circ} \mathrm{C}$, this result allowed their exclusion as factors responsible for the morphological changes. It also allowed exclusion of HLY and ACT because the mutant strain BP348 does not produce these factors.

Further evidence excluding PT and LPS as agents of morphological change in MRC-5 cells was obtained with the purified toxins. Serial 10-fold dilutions of purified PT and LPS were examined, each from $10 \mu g$ to $10 \mathrm{ng} /$ well, with crude HLT and heat-inactivated HLT as positive and negative controls. Neither PT, nor LPS, nor heat-inactivated HLT caused any morphological change, whereas the HLT-treated cells responded as already described.

\section{Quantitation of cell response}

When 10-fold dilutions of crude HLT were assayed in MRC-5 cells, the dose-response relationship shown in fig. 3 was obtained. Taking the morphological score as the indicator of toxicity, the ED50 was estimated as $6.6 \mathrm{ng}$ of crude toxin $/ 0 \cdot 2 \mathrm{ml}$. However, the minimum detectable dose of toxin was considerably smaller, c. $0 \cdot 1 \mathrm{ng} / 0 \cdot 2 \mathrm{ml}$ (fig. 3).

In addition to scoring the morphological changes by microscopy, the monolayers were fixed and stained with Giemsa solution, and the optical absorption $\left(\mathrm{A}_{540 \mathrm{~nm}}\right)$ was measured in an ELISA reader (fig. 4). The absorbance was highest for wells where the monolayer was not affected by HLT, and decreased with the greater clearing of the monolayer at the higher concentrations of toxin. The end-point was taken as the highest dilution of toxin for which the upper $95 \%$ confidence limit did not overlap the mean absorbance of the corresponding dilution of heated HLT (fig. 4).

By analysis of cell viability with the MTT in-situ

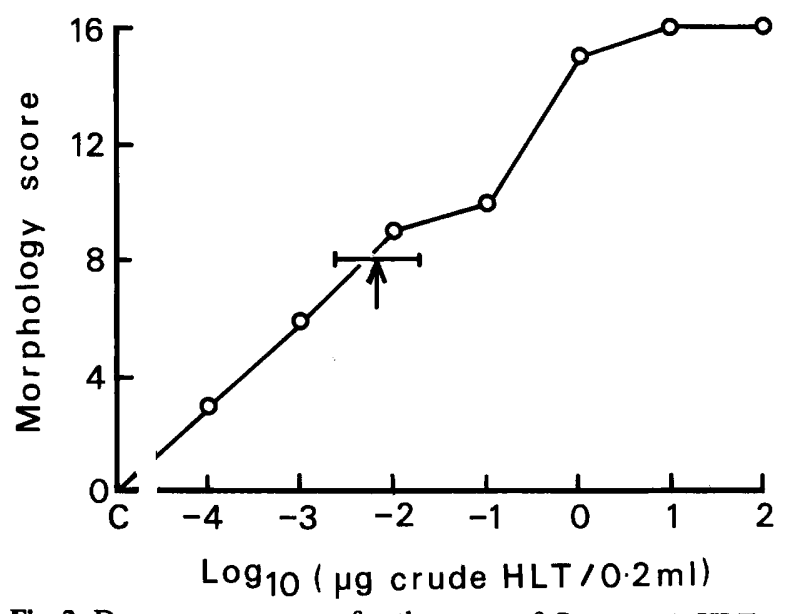

Fig. 3. Dose-response curve for the assay of $B$. pertussis HLT on MRC- 5 cells. The arrow indicates a $\log _{10}$ ED50 of $-2 \cdot 18(6.6 \mathrm{ng} /$ $0.2 \mathrm{ml}$ ) and the bar shows the $95 \%$ confidence limits.

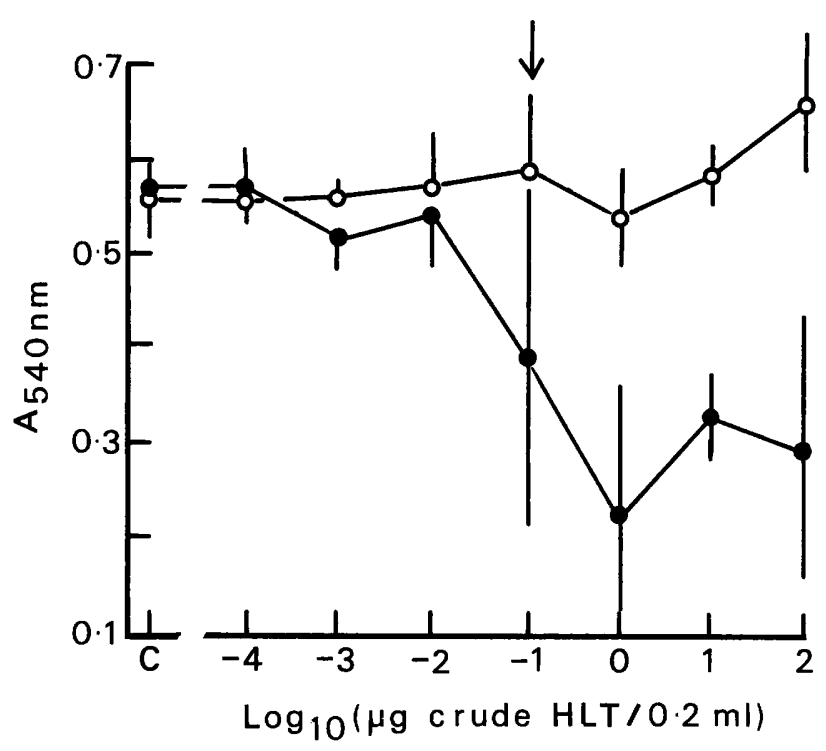

Fig. 4. Dose-response curves for the assay of $B$. pertussis HLT ( and $56^{\circ} \mathrm{C}$-heated HLT $(O)$ on MRC- 5 cells. The responses are expressed as colorimeter readings of the Giemsa-stained monolayer, with $95 \%$ confidence limits. The arrow indicates the colorimetric end-point-the lowest concentration of toxin $(0.1 \mu \mathrm{g} / 0.2 \mathrm{ml})$ for which the upper confidence limit failed to overlap with the mean of the corresponding heated-toxin control. 
colorimetric assay, and with the uptake of neutral red by MRC- 5 cells exposed to HLT for up to $96 \mathrm{~h}$, it was deduced that the toxin did not cause cell death even at the highest concentrations tested (data not shown), although the cells had undergone marked changes in shape.

\section{Comparative tests in MRC-5 cells and in mice}

Because pure HLT was not available, cytoplasmic fractions from various mutants of $B$. pertussis were tested for morphological change in MRC-5 cells and for lethal toxicity in mice (table II). These comparative tests were done on transposon-insertion mutants lacking HLY and ACT (BP348), or FHA (BP353), or with decreased levels of PT (BP357). In addition, a $\mathrm{Vir}^{-}$mutant (BP347), which lacks all virulence factors, including HLT, was assayed. Because the cytoplasmic fraction of BP347 was not toxic for MRC-5 cells, we deduce that the factor(s) responsible for morphological change in these cells was under the control of the vir gene. In contrast, the cytoplasmic fraction from other transposon-insertion mutants induced the characteristic HLT-dependent morphological change in MRC5 cells and also killed mice. These results further strengthened the conclusion that the response of the tissue culture cells was due to HLT and not to other known virulence factors of $B$. pertussis, namely HLY, ACT, FHA, PT, or LPS.

Table II. Activity of crude HLT (from virulent phase of $B$. pertussis) and cytoplasmic fractions (from transposon mutants) on MRC-5 cells and in mouse toxicity tests

\begin{tabular}{|c|c|c|}
\hline \multirow{2}{*}{$\begin{array}{c}\text { B. pertussis } \\
\text { strain (phenotype) }\end{array}$} & \multicolumn{2}{|c|}{$\begin{array}{l}\text { Toxicity end-point in } \mu \mathrm{g} \text { of protein }(95 \% \\
\text { confidence limits) }\end{array}$} \\
\hline & MRC-5 ED50 & Mouse LD50 \\
\hline $77 / 18319\left(\mathrm{Vir}^{+}\right)$ & $0.09(0.03-0.28)$ & $0.6(0.4-0.8)$ \\
\hline Tohama $\left(\mathrm{Vir}^{+}\right)$ & $0.04(0.01-0.16)$ & $5 \cdot 4(3 \cdot 7-7 \cdot 8)$ \\
\hline BP347 $\left(\mathrm{Vir}^{-}\right)$ & $>100$ & $>100$ \\
\hline BP348 $\left(\mathrm{Hly}^{-} ;\right.$Act $\left.^{-}\right)$ & $0.6(0.2-1.6)$ & $1 \cdot 0(0 \cdot 8-1 \cdot 3)$ \\
\hline BP353 $\left(\mathrm{Fha}^{-}\right)$ & $1.9(0.6-6 \cdot 2)$ & $1.2(0.9-1 \cdot 5)$ \\
\hline BP357 (PT reduced) & $0 \cdot 6(0 \cdot 3-1 \cdot 2)$ & $1 \cdot 3(0 \cdot 8-2 \cdot 1)$ \\
\hline
\end{tabular}

\section{Discussion}

HLT is principally responsible for the mouse-lethal toxicity of freshly-harvested cells of $B$. pertussis and is also produced by other species of Bordetella. Its evolutionary conservation during speciation, its toxicity and its universal presence in wild-type $B$. pertussis $^{9}$ all suggest an important role in pathogenesis or bacterial metabolism - so far not discovered. MRC5 cells offer the possibility of exploring the mode of action of the toxin at the cellular level.

In previous attempts to develop a tissue-culture assay for HLT, morphological alterations were reported in primary explant cells from human fetal brain tissue. ${ }^{19}$ Angela et al ${ }^{20}$ noted vacuolation and clustering of monolayers of HeLa cells but this was not confirmed in our laboratory; nor did Strizova and Trlifajova ${ }^{4}$ find HeLa cells sensitive to HLT. Instead, these latter authors observed that, of a number of cell types tested, only KB (a primary culture from mouse embryonic tissue) was sensitive to the toxic action of a crude cytoplasmic fraction from $B$. pertussis. The cytotoxic effect consisted of morphological alterations of the cell monolayer, apparently similar to that observed in MRC-5 cells, with clusters of damaged cells joined together by bridges of preserved tissue. This effect was also induced by preparations of toxin from $B$. parapertussis and B. bronchiseptica. However, it is doubtful whether the effect was due specifically to HLT activity because the causative agent was not inactivated by heating to $56^{c} \mathrm{C}$ for $30 \mathrm{~min}$, although exposure to $56^{\circ} \mathrm{C}$ for $60 \mathrm{~min}$ was destructive. The effect on cell viability was not investigated.

More recently, Kume et al. ${ }^{5}$ reported that purified B. bronchiseptica HLT, down to $2 \mathrm{ng} / \mathrm{ml}$, was cytotoxic for EBL (embryonic bovine lung) cells. However, as cell viability was not determined, it is possible that a morphological effect alone was observed, because these authors used the cell-rounding assay of Rutter and Luther. ${ }^{21}$ In contrast, Nakase and Endoh ${ }^{22}$ and Endoh et al. ${ }^{6}$ found that purified HLT, from $B$. pertussis or $B$. parapertussis, had no effect on embryonic lung cells and suggested that HLT acts solely on vascular smooth muscle cells. They also proposed that either the HLT of Kume et al. ${ }^{5}$ was not pure, or that the EBL cells were contaminated with smooth muscle cells. In this context it may be noted that the propagation of cell lines in vitro, even those with a finite life in culture, may result in the selection of cells that are adapted to in-vitro passage. For example, cells which divide more rapidly or stick to the substrate more effectively have a greater chance of being conserved in the cell line. ${ }^{23}$ There is thus the possibility of considerable variation in the characteristics of cell lines, despite their derivation from a similar tissue type. In the present work, HLT affected two of the human embryonic lung cell lines tested, while seven other lung cell lines (including three of human origin) were insensitive to its action. Consequently, the present positive results with MRC-5 and HELu2 cells are not inconsistent with the negative results in the single HEL cell line tested by Endoh $e t$ al. ${ }^{6}$

The present studies would have been greatly assisted by having pure HLT. However, despite several recent publications, there remains disagreement on how best to purify the toxin and also on its molecular characteristics. ${ }^{24,25}$ The results reported here with MRC-5 cells can be ascribed to HLT because the activity was affected by heat and by transposon mutagenesis in the manner predicted for this toxin. PT could be excluded as a single responsible factor, because of the inactivity of the purified PT at high doses, the known stability of PT at $56^{\circ} \mathrm{C}$, and the positive results on MRC-5 cells with the crude HLT from strain BP357, which 
produces less of this toxin than the parent strain Tohama. However, complete exclusion of an interactive effect between PT and HLT would require tests with the two pure toxins. The results with the transposon-insertion mutants BP348 and BP353 allowed exclusion of ACT, HLY and FHA as factors capable of affecting the MRC- 5 cells.

As regards sensitivity for detecting HLT, the MRC5 monolayers were better than lethality titrations in mice. With most strains, the ED50 score for the monolayers, expressed as $\mu \mathrm{g}$ of protein/well, was much smaller than the LD50 expressed as $\mu \mathrm{g}$ of protein/ mouse. The advantage was even greater if minimum reacting dose (MRD) rather than $50 \%$ end-point was used, because the cell culture assay had a shallower slope in its dose-response curve than the mouse toxicity test (not shown), and the MRD of the cell cultures was about 100 times lower than the ED50. However, the

\section{References}

1. Wardlaw AC, Parton R (eds) Pathogenesis and immunity in pertussis. Chichester, Wiley. 1988: 482.

2. Bordet J, Gengou $O$. L'endotoxine coquelucheuse. Ann Inst Pasteur 1909; 23: 415-419.

3. Wardlaw AC, Parton R. Bordetella pertussis toxins. Pharmacol Ther 1983; 19: 1-53.

4. Stř̌žová V, Trlifajová J. The neutralization of $B$. pertussis toxin in a tissue culture. J Hyg Epidemol Microbiol Immunol 1964; 8: $428-432$.

5. Kume K, Nakai T, Samejima Y, Sugimoto C. Properties of dermonecrotic toxin prepared from sonic extracts of Bordetella bronchiseptica. Infect Immun 1986; 52: 370-377.

6. Endoh M, Nagai M, Ueda T, Yoshida Y, Nakase Y. Cytopathic effect of heat-labile toxin of Bordetella parapertussis on aortic smooth muscle cells from pigs or guinea pigs. Microbiol Immunol 1988; 32: 423-428.

7. Weiss AA, Hewlett EL, Myers GA, Falkow S. Tn5-induced mutations affecting virulence factors of Bordetella pertussis. Infect Immun 1983; 42: 33-41.

8. Aricó B, Miller JF, Roy C et al. Sequences required for expression of Bordetella pertussis virulence factors share homology with prokaryotic signal transduction proteins. Proc Natl Acad Sci USA 1989; 86: 6671-6675.

9. Stainer DW, Scholte MJ. A simple chemically defined medium for the production of phase I Bordetella pertussis. J Gen Microbiol 1970; 63: 211-220.

10. Livey I, Wardlaw AC. Production and properties of Bordetella pertussis heat-labile toxin. J Med Microbiol 1984; 17: 91103.

11. Bradford MM. A rapid and sensitive method for the quantitation of microgram quantities of protein utilizing the principle of protein-dye binding. Anal Biochem 1976; 72 : 248-254.

12. Imaizumi A, Suzuki Y, Ono S, Sato H, Sato Y. Heptakis (2,6-0dimethyl) $\beta$-cyclodextrin: a novel growth stimulant for Bordetella pertussis phase I. J Clin Microbiol 1983; 17: 781786. shallower slope adversely affects the intrinsic precision of the cell culture assay and dictates the use of 10-fold spaced dilutions of toxin as being most appropriate. In contrast, the higher slope of the mouse lethality titration allows two-fold dilutions of HLT to be used effectively. The main usage of the MRC-5 cell culture assay for HLT is therefore likely to be as a "limit" test where high sensitivity and specificity, rather than high precision, are of primary importance. Obvious applications are the testing of bordetella mutants and bacterial extracts for the presence or absence of HLT. Another benefit is avoidance of the use of live animals.

This work was supported by grants from the Medical Research Council and the McGhee McMillan Medical Research Fund of Glasgow University. We are grateful to the Beatson Institute for Cancer Research, Glasgow, for the use of their tissue culture facilities, and to the Department of Virology, University of Glasgow, for the supply of several of the cell culture lines.

13. Christodoulides M, Sidey FM, Parton R, Stewart-Tull DES. An acellular pertussis vaccine prepared by a simple extraction and toxoiding procedure. Vaccine $1987 ; 5: 199-207$.

14. Jacobs JP, Jones CM, Baillie JP. Characteristics of a human diploid cell designated MRC-5. Nature 1970: 227: 168170.

15. Greaves MD, Potter CW, McEntegart MG. A comparison of the sensitivity of cell cultures to diphtheria toxin by dyeuptake methods. J Med Microbiol 1971; 4: 519-527.

16. Mosmann T. Rapid colorimetric assay for cellular growth and survival: application to proliferation and cytotoxicity assays. J Immunol Methods 1983; 65: 55-63.

17. Takano S, Kondo H. Quantitative method for determination of hemolytic activity of Clostridium septicum toxin. Jpn J Med Sci Bio 1987; 40: 47-59.

18. Fairweather DS, Fox M, Margison GP. The in-vitro lifespan of MRC- 5 cells is shortened by 5 -azacytidine-induced demethylation. Exp Cell Res 1987; 168: 153-159.

19. Felton HM, Gaggero A, Pomerat CM. Reactions of cells in tissue culture to Hemophilus pertussis. Tex Rep Biol Med 1954; 12: 960-971.

20. Angela GC, Rosso C, Guiliani G. Effetto della tossina pertossica sulle cellule coltivate in vitro. Minerva Med Roma 1962; 53: 778-784.

21. Rutter JM, Luther PD. Cell culture assay for toxigenic Pasteurella multocida from atrophic rhinitis of pigs. Vet $\operatorname{Rec} 1984$; 114: 393-396.

22. Nakase Y, Endoh M. Heat-labile toxin of Bordetella pertussis. In: Wardlaw AC, Parton R (eds) Pathogenesis and immunity in pertussis. Chichester, Wiley. 1988: 211-229.

23. Freshney RI. Introduction: principles of sterile technique and cell propagation. In: Freshney RI (ed) Animal cell culture a practical approach. Oxford, IRL Press. 1986: 1-11.

24. Zhang Y-L, Sekura RD. Isolation and characterization of heat labile toxin (HLT) from Bordetella pertussis. Federation Proc 1985; 44: 674

25. Endoh M, Amitani M, Nakase Y. Purification and characterization of heat-labile toxin from Bordetella bronchiseptica. Microbiol Immunol 1986; 30: 659-673. 